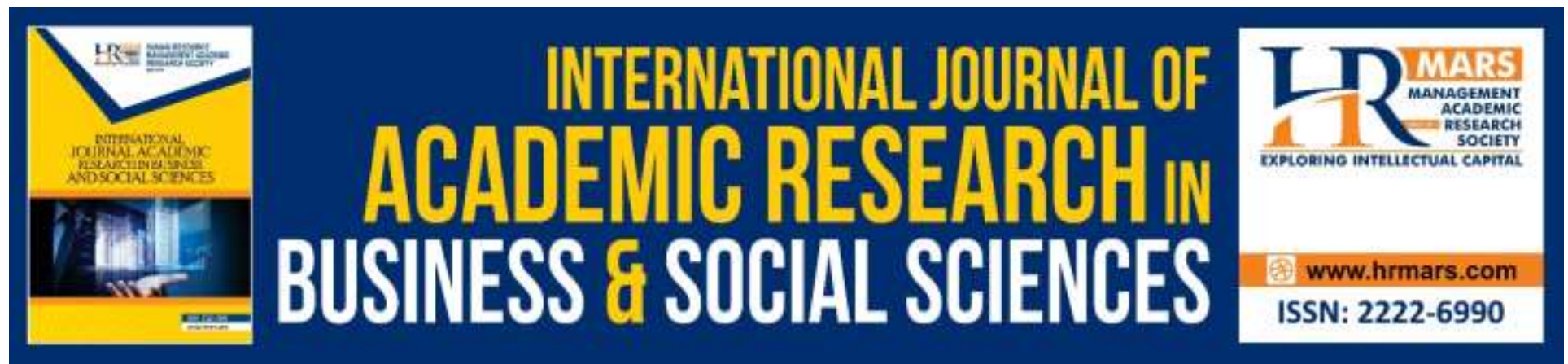

\title{
Leadership Style and Job Satisfaction among Malaysian Army College Officer
}

\author{
Mohd Ghazali Abdul Rahman, Mohd Yusuf Abdullah, Wan Norhayati Wan \\ Othman, Zaida Nor Zainuddin, Yusni Mohamad Yusup
}

To Link this Article: http://dx.doi.org/10.6007/IJARBSS/v9-i11/6635

DOI: 10.6007/IJARBSS/v9-i11/6635

Received: 11 October 2019, Revised: 29 October 2019, Accepted: 04 November 2019

Published Online: 28 November 2019

In-Text Citation: (Rahman, Abdullah, Othman, Zainuddin, \& Yusup, 2019)

To Cite this Article: Rahman, M. G. A., Abdullah, M. Y., Othman, W. N. W., Zainuddin, Z. N., \& Yusup, Y. M. (2019). Leadership Style and Job Satisfaction among Malaysian Army College Officer. International Journal of Academic Research in Business and Social Sciences, 9(11), 1063-1072.

Copyright: (C) 2019 The Author(s)

Published by Human Resource Management Academic Research Society (www.hrmars.com)

This article is published under the Creative Commons Attribution (CC BY 4.0) license. Anyone may reproduce, distribute, translate and create derivative works of this article (for both commercial and non-commercial purposes), subject to full attribution to the original publication and authors. The full terms of this license may be seen

at: http://creativecommons.org/licences/by/4.0/legalcode

Vol. 9, No. 11, 2019, Pg. 1063 - 1072

Full Terms \& Conditions of access and use can be found at http://hrmars.com/index.php/pages/detail/publication-ethics 


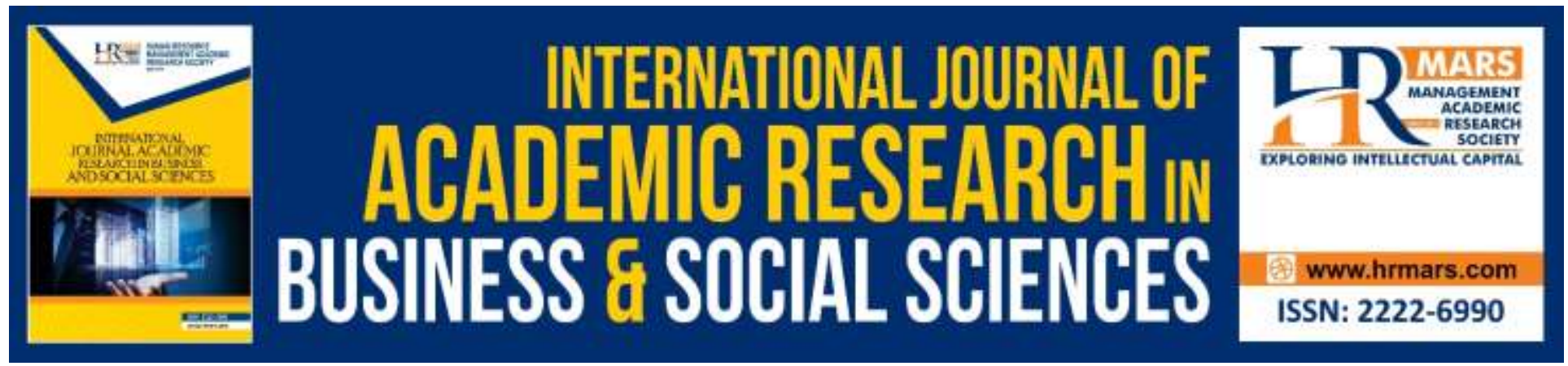

\title{
Leadership Style and Job Satisfaction among Malaysian Army College Officer
}

\author{
Mohd Ghazali Abdul Rahman, Mohd Yusuf Abdullah
}

Faculty of Language and Education, Kolej Universiti Islam Melaka

\author{
Wan Norhayati Wan Othman, Zaida Nor Zainuddin, Yusni \\ Mohamad Yusup \\ Faculty of Educational Studies, Universiti Putra Malaysia \\ Email: wannorhayati@upm.edu.my
}

\begin{abstract}
Job satisfaction is regarded as a generally favorable or unfavorable attitude resulting from specific work areas, such as job factors, individual characteristics, and group relationships outside of work. The objective of this study is to determine the relationship between leadership styles to job satisfaction among Malaysian Army College Officer. This research is based on quantitative research methodology and a cross-sectional survey research design. The 52 sample was selected by using a random sampling method to represent the whole 60 population of officer working at Army Collage in Port Dickson. Based on the findings of the study, there is no significant relationship between authoritarian leadership style and laissez-faire leadership style and there was significant relationship between democratic leadership style with job satisfaction. This means that employees were democratic leadership style with their current job, it does affected to the level of their job satisfaction and their performance. This research will give benefit to the General of Command in Training and Doctrin (GOCTRADOC) and Commandant of Centre of Excellences Malaysian Army to get competent and quality also may solve shortage qualified instructor and lecturer.
\end{abstract}

Keywords: Leadership Style, Job Satisfaction.

\section{Introduction}

Job satisfaction is an emotional and affective response to feelings of like or dislike (Muchinsky, 1993). Amburgey (2010) states that job satisfaction is an important element of an organization. Early definitions suggest that job satisfaction is viewed as a favorable or unfavorable attitude as a result of certain workplaces, such as job factors, individual characteristics and group 
relationships outside of work (Blum \& Naylor, 1968). Attitude is defined as the beliefs, feelings, and tendencies of actions that shape the judgment of one's work environment (Lowenberg \& Conrad, 1998). This study involves international literature on exploration and theories of interactions between leadership styles (autocratic, democratic and laissez-faire) and work commitment with a focus on work exploration and modernization of phenomena in an Army College. The relationship between the leadership style of the principal (director) and the job satisfaction of faculty members has been studied by many researchers. Muhammad Amin, Saeeda, ljaz (2013) also studied the relationship between leadership style and job satisfaction. Although leadership is found to affect the attitude and performance of its followers, there is a gap in leadership research in this study. The purpose of this paper is to study the relationship of leadership style to job satisfaction of military personnel at the Army College.

Identifying the presence of leadership style whether authoritarian, autocratic or lesseesfaire, and developing workplace and manage workplace motivation are three responsibilities factors influence toward maintaining employee job satisfaction and productivity (Love \& Edwards, 2005). AlRub (2014) held that job satisfaction are contributing factors to organizational inefficiencies, high staff turnover, absence of illness, decreased quality and quantity of care and increased health care costs.

Every each army personnel should be understand what their task, duty and responsibility are to protect country's sovereignty and ensure peaceful life of citizens. By an Army Officer, the responsibility more heavy because they are role model to the ordinary army personnel. Their professionalism must in high state at any time to ensure the enemy always defeated. For the Malaysian Army, employee job satisfaction is comes first, so that the quality of work performed and in accordance with the services requirement. In this study, researchers tried to identify the relationship between job satisfaction and leadership style.

Thus, several of social problems, mental impairment and discipline among Malaysian Army College Officer. Amongst the problems that often occur among Malaysian Army College Officer such as contracts not renewed, family problems, financial problems, substance abuse problems, leaving the job for a long time, resign early and common discipline. The phenomenon of misconduct and the case of discipline by some officers of the Malaysian Army College Officer such as rape female students in IKEM, it involving military officers attending a course at the IKEM for nine months and had to be discharged from the course due to pregnancy (News Straits Times, 2013) and cases of extortion of a student in the IPDA (Utusan Malaysia, 2014). When military officers linked to the misconduct and discipline, it leads to perceptions and accusations are not good in society and indirectly through a small number but it can affect the good name and bring a bad image to the Malaysian Armed Forces (ATM). Other than that, the defense system is one of the factor in determining a progress and peace in the country. The growth demand to be an army officer is increase at every day but, despite how many a number of an army officers and how sophisticated a military machine in the country, if people who machine operator in delirium condition and not sincere in working behavior of course the defense in that particular country will become fragile (Basiron, 2008). The social behavior problem, will portrait negative stigma to the public's (citizens) perceives that many in an army officer just think about money rather than 
main responsibility at work. This is might happened due to incomprehensive military training, heavy workload in work place, leadership issues or job satisfaction.

This research will give benefit to the General of Command in Training and Doctrin (GOCTRADOC) and Commandant of Centre of Excellences Malaysian Army to get competent and quality also may solve shortage qualified instructor and lecturer.

The objective of this study is to identify the level of job satisfaction among an Malaysian Army College Officer and to determine the relationship between leadership style to job satisfaction among Malaysian Army College Officer.

\section{Job Satisfaction}

Job satisfaction is defined as the general feeling or attitude of the worker in relation to their job and work components such as the work environment, working conditions, fair pay, and communication with colleagues (Kim, 2010). Many models or theories have been applied to job satisfaction. According to Robbins and Judge (2009), job satisfaction describes positive feelings about work, as a result of evaluating its characteristics. People with high job satisfaction have positive feelings about their job, while people who are dissatisfied with their job have negative feelings. Job satisfaction is a positive experience that comes from one's work experience (Locke, 1976).

\section{Leadership Style}

Leadership is a universal human phenomenon, as well as a sophisticated concept. The term "leadership" has been defined and conceptualized in many different ways and in different leadership theories. Leadership is primarily concerned with how leaders influence change and motivates followers to make changes (Amin, Saeeda \& ljaz, 2013).

The approach of traits was one of the first systematic attempts to learn leadership in the early 1900s (Bass, 1981; Northouse, 1997). Trait theory, developed by the beliefs of the "great man", focuses on identifying the natural attributes and characteristics of great social, political, and military leaders (Northouse, 1997). More importantly, this theory shows that these traits are inherent rather than nurtured through skilled parenting or extensive schooling (Konto, 1986). Stogdill (1974) conducted two surveys that reviewed the nature of leadership. Stogdill's first study combines eight key leadership traits, including intelligence, vigilance, insight, responsibility, initiative, perseverance, self-confidence, and friendliness. These characteristics are related to how people in different groups become leaders.

In the literature, on job satisfaction, this is evidence from the study of Muhammad Amin, Saeeda and Ahmad (2013), this study aims to explore the interaction between leadership style (transformative, transactional and laissez-faire) and job satisfaction (intrinsically, extrinsically and overall) at Pakistan public universities faculty members. This study is cross-sectional and analytical in nature. All faculty, 287 faculty, selected universities were defined as samples. The findings indicate that there is a significant relationship between groups of independent variables (transformational leadership style, transactional and laissez-faire) and intrinsic, extrinsic and overall faculty satisfaction. However, the independent variable group had a stronger relationship 
with extrinsic job satisfaction than overall job satisfaction, and the independent variable relationship with intrinsic job satisfaction was slightly stronger. Transformational leadership styles, related to two independent variables (transactional and laissez-faire leadership styles), have a positive and statistically significant impact on intrinsic, extrinsic and overall faculty satisfaction. Whereas laissez-faire leadership style, relative, has a weak positive and negative impact on intrinsic, extrinsic and overall faculty satisfaction. The transactional leadership style, on the other hand, had a negative and non-significant negative impact on intrinsic, extrinsic and overall faculty satisfaction.

\section{Methodology}

The research method of this study is based on quantitative and a cross-sectional survey research design. The random sample technique was applied throughout this study. It was chosen because each person in the population has the same probability of being selected and selection of one individual is independent of the selection of any other (McBurney, 2009). The target population for the current study was an Army College Officer that duty in Port Dickson and a random sample was selected from the target population. In determine the sample size of respondents, the sampling size procedure as suggested by Mogan and Krejcie (1970) was applied. Since the population of Army Collage Officer was 60 during the research period, the recommended sample size for this population was 52 with a confidence level of $95 \%$ and a margin of error (degree of accuracy) of $5 \%$. The sample was selected by using a random sampling method to represent the whole population of officer working at Army Collage in Port Dickson area. This research used instrument in from 3 section. Section A is about Demographic Information. Section B is the Job Satisfaction Scale (JSS) to measure respondent job satisfaction and section C is Leadership Style Scale to measure respondent leadership style.

a. Section A; Demographic

This section of Demographic Information consist six item. The items are (a) Rank (b) age (c) ethnicity (d) marital status (e) education level (f) place were the respondent graduated.

b. Section B: Job Satisfaction Scale (JSS)

This questionnaire design by Scott Macdonald and Peter Maclntyreshort (1997). This scale consist 10 items and utilizing a Five point Likert scale. The value of 1 represent 'strongly disagree', 2 'represent Disagree', 3 refer to 'don't know', 4 refer to 'agree' and 5 refer to 'strongly agreed'.

c. Section C: Leadership Style Scale (LSC)

This questionnaire contains statements about leadership style beliefs. It's design by Doncalrk (2010). This scale consist 18 items and utilizing a Five point Likert scale. The value of 1 represent 'strongly disagree', 2 'represent Disagree', 3 refer to 'neutral', 4 refer to 'agree' and 5 refer to 'strongly agreed'. LSC divided three style of leadership where it's Authoritarian Leadership, Democratic Leadership and Laissez-Faire Leadership. 
INTERNATIONAL JOURNAL OF ACADEMIC RESEARCH IN BUSINESS AND SOCIAL SCIENCES

Vol. 9, No. 11, November, 2019, E-ISSN: 2222-6990 @ 2019 HRMARS

\section{Findings}

Research Objective 1: Identify the level of job satisfaction among an Army College Officer Level of Job Satisfaction among Army College Officer consist three level. It's Very High, High and Average. Overall Job Satisfaction among Army Officer are at level High. The summary of the descriptive statistics is shown in Table 1

Table 1

Overall Job Satisfaction Among Army College Officer

\begin{tabular}{lcc}
\hline Level of Job Satisfaction & $\begin{array}{c}\text { Frequency } \\
\mathrm{N}=52\end{array}$ & Percent (\%) \\
\hline Very High & 9 & 17.3 \\
High & 42 & 80.8 \\
Average & 1 & 1.9 \\
Total & $\mathbf{5 2}$ & $\mathbf{1 0 0}$ \\
\hline
\end{tabular}

The results show that mostly the level of Job Satisfaction of an Army College Officer at level High 42 respondent (80.8\%), 9 respondent (17.3\%) at level Very High and only 1 respondent (1.9\%) at level average.

Research Objective 2: To determine the relationship between leadership style to job satisfaction among Malaysian Army College Officer

Table 2

Person Product-moment Correlation Between Authoritarian, Democratic, Laissez-faire Leadership Style and Job Satisfaction

\begin{tabular}{llccc}
\hline & 1 & 2 & 3 & 4 \\
\hline 1. Authoritarian Leadership Style & 1 & $.85^{* *}$ & $.82^{* *}$ & .20 \\
2. Democratic Leadership Style & & 1 & $.77^{* *}$ & $.35^{* *}$ \\
3. Laissez-faire Leadership Style, & & & 1 & .14 \\
4. Job Satisfaction & & & & 1 \\
\hline
\end{tabular}
** $\mathrm{p}<.001$

The relationship between Authoritarian, Democratic and Laissez-faire Leadership Style with Job Satisfaction was investigated using Pearson product moment correlation coefficient. The result at table 1 show that there was a positive and significant correlation between democratic leadership style and job satisfaction, $r=.35, p<.001$. 


\section{Discussions}

Research Objective: To determine relations between leadership style with job satisfaction among Malaysian Army College Officer

Based on the findings of the study, there is no significant relationship between authoritarian leadership style and laissez-faire leadership style and there are significant relationship between democratic leadership styles with job satisfaction. This means that employee with democratic leadership style affected to the high level of their job satisfaction. Therefore military officers need to adopt a democratic leadership style to ensure that they are always satisfied with their work and career as an army in order to maintain work performance, to decrease turnover or absent from work.

\section{Recommendation to Ministry Of Defense}

Democratic Leadership Style of officer and high employee commitment is the dream of all organizations. The results from the study shows that there are significant relationship between job satisfaction and Democratic Leadership Style, so that, apply Democratic Leadership Style will necessarily lead to high level of the employee job satisfaction and high performance in work. For an organization to be successful, its managers should focus on increasing the employees' job satisfaction in factors such as the work itself, benefit programs, rewards, work conditions, an promotions. These can influence the way a person would feel and perceive about their jobs. Indeed, managers may also apply job rotation so each employee will have an opportunity to perform different tasks using various skills and talents.

By using this method, it may further enhance the interest that employees have in their work. In addition, managers may also decide to use a reward system to identify employees who perform their duties well. Indeed, one will feel very happy when he or she is rewarded for their hard work and excellent performance. Rewards can take different forms, such as higher wages, improved work environments (safer and better facilities for workers), and appropriate and challenging work assignments to individuals according to their abilities and personalities. Moreover, managers should motivate employees to be more helpful, considerate, friendly and friendly to their co-workers and supervisors, as this will enhance employee satisfaction and motivate employees to help other employees. Indeed, providing enough opportunities for promotion to employees will significantly increase job satisfaction as promotion reflects a valuable signal of one's self-esteem.

The organizations must increase cooperation among employees to improve the relationships among employees in each department. Managers can carry out external or team building activities and must join all employees in the organization. Accordingly, the relationship between employer and employee can also be improved. These findings highlight the importance of creating and nurturing an environment in which to maintain good relationships, both parties must be prepared to complement, appreciate and reciprocate with each other. Practically, if an employer wants the employee to be committed to the organization, the employer needs to pay full attention and emphasize the quality of job satisfaction among their employees. Finally, future research can be carried out in greater detail in this study in enhancing organizational 
commitment and satisfaction. Additionally, this study can be done on a larger scale and can involve Army Officers from all over Malaysia.

\section{Recommendation for Future Researchers}

This study provides only a small overview of the relationship between Leadership Style and job satisfaction in the context of the Army College Officer. Therefore, it is useful for future research to consider the following suggestions: Extend the study to other areas by examining the relationship of Leadership Style, Motivation and Organizational Commitment and job satisfaction in the Ministry of Defense. Finally, it is hoped that this study will benefit everyone involved in Higher Education Institutions, including those involved in academic research, students, end users, and various practitioners in this sector.

\section{Conclusion}

Based on correlation analysis, democratic leadership style is the best factor clearly correlated to job satisfaction. Therefore, the Army College can use these results to shaping the employees satisfaction to the organization. In addition, the finding of this study can also help the organization in planning and developing the strategies to enhance the job satisfaction of the employees. It may become one of the tool and guidance for further actions. This is important to keep the survival of the organization in the global era whereby nowadays it is not easy to make employees to feel obliged and become committed to the organization. So, new strategies must be developed from time to time and it depends on the result of this kind of study.

Herzberg's two-factor theory was used as the main theoretical framework in this study. In his theory Herzberg has listed the complete dimensions of human work satisfaction such as supervision and policy and organizational administration. In addition, there are other theories that have been backed up to further strengthen the effectiveness of this study. Among other theories such as Trait Theory and Behavior Theory on leadership style influence job satisfaction. Therefore, the results of this study can strengthen and see the effectiveness of theory in human life.

This research also will give benefit to the General of Command in Training and Doctrin (GOCTRADOC) and Commandant of Centre of Excellences Malaysian Army to get competent and quality also may solve shortage qualified instructor and lecturer.

\section{Acknowledgement}

This research received no specific grant from any funding agency in the public, commercial or not-for-profit sectors.

\section{Corresponding Author}

Wan Norhayati Wan Othman

Department of Counsellor Education \& Counselling Psychology, Faculty of Educational Studies Universiti Putra Malaysia

Email:wannorhayati@upm.edu.my 
INTERNATIONAL JOURNAL OF ACADEMIC RESEARCH IN BUSINESS AND SOCIAL SCIENCES

Vol. 9, No. 11, November, 2019, E-ISSN: 2222-6990 @ 2019 HRMARS

\section{References}

Amburgey, W. O. (2005). An analysis of the relationship between job satisfaction, organizational culture, and perceived leadership characteristics. Doctoral dissertation. University of Central Florida.

Ayeni, C. O., \& Phopoola, S. O. (2007). Work Motivation, Job Satisfaction, and Organizational Commitment of Library Personnel in Academic and Research Libraries in Oyo State. Nigeria: Library Philosophy and Practice.

Lumley, E. J. M., Coetzee, R. T., \& Ferreira, N. (2011). Exploring the job satisfaction and organizational commitment of employees in the information technology environment. Southern African Business Review Volume 15 Number 1, 100-118

Faragher, E. B., Cooper, C. L., \& Cartwright, S. (2004). A shortened stress evaluation tool (ASSET). Stress and Health, 20, 198-201.

Getahun, S. B., Sims, Hummer, D. (2008). Job Satisfaction and Organizational Commitment among Probation and Parole Officers: A Case Study. A Professional Journal, 3(1).

Grosso, F. V. A. (2008). Motivating Faculty through Transformational Leadership: A Study of the Relationship between Presidential Leadership Behaviors and Faculty Behaviors. Doctor of Philosophy Thesis. The Catholic University of America, Department of Education.

Krejcie, R. V., \& Morgan, D. W. (1970). Determining sample size for research activities [Electronic version]. Educational and Psychological Measurement, 30, 607-610.

Lambert, E. G. (2004). Organizational citizenship behavior and commitment among correstional staff. Criminal justice and behavior 35(1).

Luchak, A. A., Pohler, D. M., \& Gellatly, I. R. (2008). When Do Committed Employees Retire? The Effects Of Organizational Commitment On Retirement Plans Under A Defined-Benefit Pension Plan. Human Resource Management, 47(3), 581-599

Lumley, E. (2010). Exploring the relationship between career anchors, job satisfaction and organizational commitment. Master's Dissertation. Department of Industrial and Organizational Psychology, University of South Africa, Pretoria.

Malhorta, N., \& Mukerjee, A. (2004). The relative influence of organizational commitment and job satisfaction on service quality of customer contact employees in banking call center. Journal of services marketing 18(3), 162-174.

McBurney, D. (2009). Research Methodology. USA: Wadsworth Thomsom Learning.

Meyer, J., \& Allen, N. (1991). 'A three component conceptualization of organizational commitment', Human Resource Management Review, 1, 61-89.

Meyer, J. \& Allen, N. (1997). Commitment in the Workplace: Theory, Research and Application. London: Sage.

Amin, M., Shah, S., Tatlah, I. A. (2013). Impact of Principals/Directors' Leadership Styles on Job Satisfaction of the Faculty Members: Perceptions of the Faculty Members in a Public University of Punjab, Pakistan. Journal of Research and Reflections in Education. Vol.7, No.2, $97-112$

Ismail, N. (2012). Organizational Commitment and Job Satisfaction among Staff of Higher Learning Education Institutions in Kelantan. Master Disertation. UUM 
Porter, L. W. \& Smith, F. J. (1970). The Etiology of organizational commitment. Unpublished manuscript, University of California at Irvine.

Kumar, R. (2014). Research Methodology: A step by step guide for beginners. USA: SAGE Publication Ltd

Singh, S. K., \& Tiwari, V. (2011). Relationship between Motivation and Job Satisfaction of the White Collar Employees: A Case Study. Management Insight Vol. VII, No. 2;

Saari, L. M., \& Judge, T. A. (2004). Employee Attitudes and Job Satisfaction. Human Resource Management, 43, 395-407

Azeem, S. M. (2010). Job Satisfaction and Organizational Commitment among Employees in the Sultanate of Oman. Psychology, 2010, 1, 295-299

Teck-Hong, T., \& Waheed, A. (2011). Herzberg's Motivation-Hygiene Theory and Job Satisfaction in the Malaysian Retail Sector: The Mediating Effect of Love of Money. Asian Academy of Management Journal, Vol. 16, No. 1, 73-94. 